\title{
EVROPSKA DIMENZIJA POUČEVANJA O ALPAH
}

\author{
Tatjana Resnik Planinc*
}

Izvleček

UDK 91:37(234.3)

Alpe so s svojo lego v več evropskih državah lahko izjemen dejavnik povezovanja in skupnega preučevanja tako $v$ osnovni kot $v$ srednji šoli. S skupnimi projekti šol alpskih dežel bi lahko uresničili mnoge izmed ciljev, ki so zapisani v Zeleni listini o evropski dimenziji izobraževanja. $V$ prispevku je predstavljenih nekaj možnosti sodelovanja na področju geografije med šolami alpskih dežel.

Ključne besede: evropska dimenzija izobraževanja, pouk geografije, sodelovanje, skupni projekti, šole alpskih držav

EUROPEAN DIMENSION OF TEACHING ABOUT ALPS

\section{Abstract}

Situated in several European states, Alps can be an extraordinary factor of connection and mutual study in the whole school vertical. With joint projects of the schools of Alpine countries many goals, written in the Green Paper on the European Dimension of Education, could be fulfilled. The article presents such possibilities of cooperation in the field of geography.

Key words: European dimension of education, geography teaching, cooperation, joint projects, schools of Alpine countries

\footnotetext{
* Mag., asistent, Oddelek za geografijo, Filozofska fakulteta, Univerza v Ljubljani Aškerčeva 2, SI-1000 Ljubljana, Slovenija
} 


\section{GEOGRAFIJA IN SODOBNI EVROPSKI IZOBRAŽEVALNI TOKOVI}

Na področju izobraževanja se je $\mathrm{v}$ Evropi od srede sedemdesetih let izrazito povečalo število dejavnosti tako po obsegu kot po pomenu. Evropska unija si je ob upoštevanju raznolikosti nacionalnih tradicij izobraževanja zastavila za cilj povečano izmenjavo informacij in izkušenj, večjo pomoč pri mobilnosti učencev in študentov ter pomoč pri razširjanju znanja. S tem namenom je sprožila vrsto programov, za katere je značilen nadnacionalni značaj, težišče pa je na razvoju programov izmenjave in ustvarjanju mrež za podporo sodelovanju udeležencev v skupnih projektih.

Koncept "evropske dimenzije izobraževanja" vključuje številne ideje, ki imajo dobro podlago $\mathrm{v}$ političnih, socioloških in izobraževalnih teorijah in so za učitelja zelo pomembne. Med njimi naj omenimo primerjavo krajev, politično zavest, državljanstvo in državljanske pravice, kulturno zavest, razumevanje, strpnost, predsodke in nacionalizem. Glede na teorije izobraževanja, prakso in evropsko dimenzijo je pomemben del tega sklopa tudi "narava skupnosti", tako na družinski, šolski, krajevni in državni kot na evropski in svetovni ravni.

\section{Uvajanje evropske dimenzije zahteva od učiteljev:}

- da se seznanijo z današnjo Evropo in možnostmi njenega razvoja,

- da se naučijo posredovati učencem bogastvo evropskih kultur,

- da uveljavljajo poznavanje skupne evropske kulturne dediščine ter evropskih organizacij,

- da presežejo kulturne in jezikovne ovire in razvijajo večjezično in večkulturno delovanje.

Vir: Zelena listina o evropski dimenziji izobraževanja, 1993, nav. po Resnik Planinc, 1998.

Geografija se pogosto omenja kot predmet, ki ima bolj kot drugi predmeti možnost, da spreminja stereotipna stališča in omogoča razumevanje interakcij človeške družbe v prostoru. 


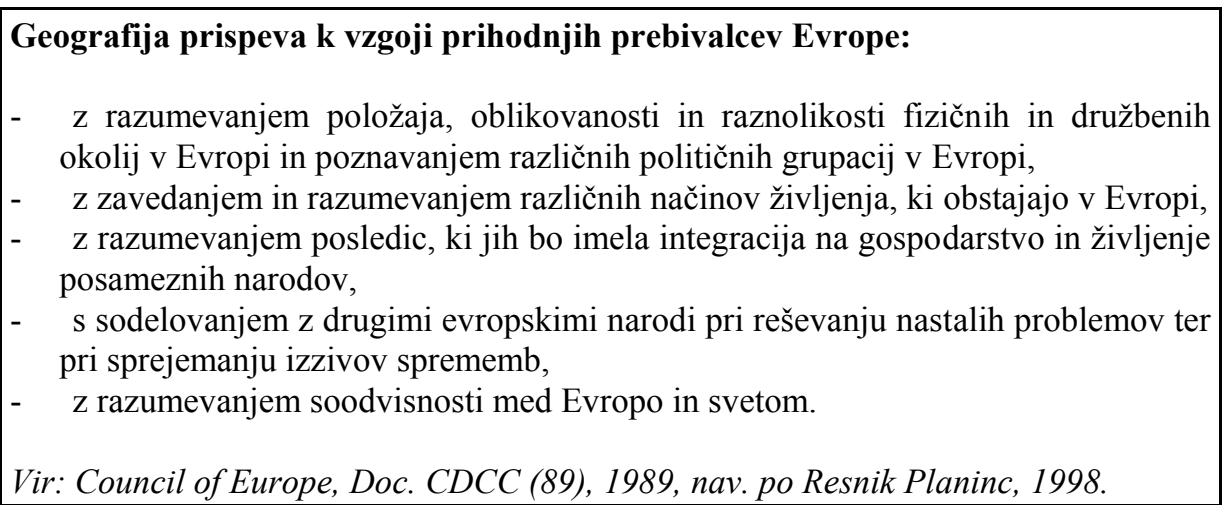

Z vstopom Slovenije v Evropsko unijo se bodo morale tudi slovenske šole dejavno vključiti v evropske izobraževalne tokove in projekte - taka prihodnost ni nujna le za celotno izobraževalno skupnost, temveč je tudi osnova evropske stvarnosti, je prizadevanje za novo Evropo. Evropska dimenzija prihaja v Slovenijo v času, ko kot mlada država doživljamo številne življenjsko pomembne spremembe. Izobraževanje je del širšega sistema delovanja države in je kot tako v veliki meri odvisno od dogajanja, na katerega nima velikega vpliva. Politične, gospodarske in družbene spremembe pogosto zasenčijo pomen izobraževanja, kar je seveda že v izhodišču zgrešeno. Če verjamemo vsem evropskim listinam, deklaracijam, resolucijam in dokumentom, potem se skuša Evropa takim napakam izogniti in vsaj na papirju izobraževanju pripisuje njegov stvarni pomen (Resnik Planinc, 1998, 244 - 246). 


\section{Vprašanja, ki so učitelju v pomoč}

- Ali poskušam predstaviti dejansko resnico o evropskih državah ali pa se preveč zanašam na vire iz druge roke, ki morda ne veljajo več?

- Ali precenjujem/podcenjujem razlike med različnimi evropskimi državami?

- Kako položaj moje države vpliva na moj izbor gradiva o Evropi kot celoti?

- $\quad$ Ali sem dobro informiran(a) o političnih stališčih o "Evropi", ki jih posredujejo državna vlada, vlade drugih evropskih držav, Evropska komisija in Svet Evrope?

- $\quad$ Kako se odzivam na "ton" teh stališč?

- Kako naj preverjam reakcije učencev na ta stališča?

- Kako povezujem vprašanja o vlogi, pravicah in dolžnostih državljana s svojim razumevanjem geografije?

- Katere so bistvene razlike med "biti državljan" na državni oziroma evropski ravni?

- Kako bo ideja "odprtih mej" v Evropi vplivala na moje poučevanje geografije?

- $\quad$ Ali sta mi geografija in večkulturno izobraževanje doma v pomoč pri poučevanju o večkulturni Evropi?

- Ali ob pomoči kolegov jezikoslovcev lahko uporabljam učno gradivo v drugih evropskih jezikih?

- Ali nadgrajujem svoje razumevanje z najnovejšimi dosegljivimi informacijami?

- Ali poskušam v razredu zagotoviti objektivno razlago o drugih evropskih državah in narodih (npr. izogibanje žaljivim šalam)?

- $\quad$ Ali, kolikor je to mogoče, preverjam znanje in razumevanje učencev, preden jih začnem učiti in po možnosti tudi potem?

- Kako prepričam učence, ki imajo predsodke o določeni evropski državi in njenih prebivalcih, da je moje poučevanje objektivno?

- Kako moj način poučevanja geografije pripomore k zvišanju pragu strpnosti med mojimi učenci?

- Do katere meje naj bi učence spodbujal(a) $\mathrm{k}$ neodvisnemu razmišljanju o družbenih in moralnih vprašanjih ter dejavni skrbi za človekove pravice?

(Convey, 1994, 215-216, nav. po Resnik Planinc, 1998) 


\section{MEDNARODNO SODELOVANJE NA PODROČJU IZOBRAŽEVANJA V EVROPI}

V državah članicah Evropske unije se vedno bolj uveljavlja mednarodno sodelovanje, ki vključuje učitelje, učence in šole. Sodelovanje sega vse od skupnih projektov do krajših in daljših izmenjav med učitelji in učenci. Na voljo je vedno več poročil o različnih oblikah sodelovanja, izkušnjah, metodah in oblikah dela. Vedno več učiteljev se odloča za tovrstno sodelovanje, ki pa zahteva od njih dodatno izobraževanje, zavzetost in veliko dela. Pogosto ne vedo, kaj jih čaka ob zaključku nekega projekta oziroma izmenjave. Vendar mora vsako izobraževanje, ki ima namen obogatiti človeka, vključevati odprtost do drugih ljudi, do novih pristopov. To je cena efektivnega prenosa znanja. V resnično demokratičnih družbah odločitve ne morejo biti poenostavljene in sklepi ne črno-beli. Naše izobraževanje pa žal pogosto še vedno temelji na količini in linearni akumulaciji znanja.

Nekega dne bomo morali spoznati, da samo prenašanje vrednot na prihodnje generacije le $\mathrm{s}$ težavo pomaga mladim ljudem pri reševanju njihovih osnovnih problemov. Če želi evropska družba poiskati boljše poti, bo morala biti osnovna naloga izobraževalnih sistemov sprejetje razlik in njihova pozitivna uporaba, sposobnost pričakovanja in soočenja $\mathrm{z}$ nepričakovanim ter dojemanje poučevanja kot kohezivnega, interaktivnega in kolektivnega procesa, kajti izobraževanje ni le zaporedje vzporednih, ločenih dejanj, ki temeljijo predvsem na posameznih šolskih predmetih (Teaching ..., 1993, 13-15).

Izmenjave med šolami, učitelji in učenci so izobraževalna izkušnja, ki presega togost centraliziranih ustanov in prispeva $\mathrm{k}$ dinamiki in razpravi o številnih in različnih zahtevah. $\mathrm{Z}$ oblikovanjem medšolskih izobraževalnih programov preprečujemo centralizacijo, ustvarjamo nove povezave in omrežja ter prispevamo k sodelovanju in dialogu.

Šole, učitelji ter učenci naj bi sodelovali zaradi:

- novih učnih metod,

- novih informacij,

- novih načinov dela in pristopov,

- ustvarjalnosti.

Pri tem moramo upoštevati 3 načela:

\section{Povezovanje učencev iz različnih držav}

Učitelji, ki se odločijo za pripravo, organizacijo in vodenje izmenjave in pri tem nimajo v mislih le obiska tuje šole, imajo pred seboj ambiciozen cilj, ki vključuje: 
- $\quad$ izboljšanje razumevanja drugih narodov in odprtost do njihovih kultur z vidika že obstoječih večjezičnih in večkulturnih družb (Belgija, Švica) in družb prihodnosti (Evropska unija),

- boljše razumevanje sebe in drugih, kar vključuje preseganje predsodkov in zgodovinskih zamer, ki so dolgo ločevale sosednje narode,

- izboljšanje znanja jezikov, kar je del, čeprav ne vedno glavni, skupnega odkrivanja in bogatitve,

- $\quad$ spoznavanje fizičnih in družbenogeografskih elementov tujih pokrajin.

\section{Enakopravnost in recipročnost, ki vplivata na status udeležencev in organizacijo srečanj}

Pri tem je potrebno:

- da imajo vsi sodelujoči enakovreden položaj,

- $\quad$ sprejeti medsebojno odvisnost,

- $\quad$ da se obvežemo za sodelovanje in pričakujemo to tudi od druge strani,

- $\quad$ sprejeti dejstvo, da je druga oseba upravičena do kritike in obratno.

\section{Skupno delo}

Skupna dejavnost je upravičeno pojmovana kot pomoč pri vzpostavljanju stikov med ljudmi, ki se ne poznajo ali ne govorijo istega jezika. Namen skupnega dela nadgrajuje šolske učne programe. Tu ni mišljena serija vsebin ali skupek znanj, ki naj bi jih preverjali in ocenjevali, temveč doseganje osrednjih ciljev sodelujočih: komunikacija, spoznavanje drug drugega in vzpostavljanje stikov ( Teaching ..., 1993, 17-24).

\section{MOŽNOSTI SODELOVANJA MED ŠOLAMI ALPSKIH DRŽAV}

Alpe so s svojo lego v več evropskih državah lahko izjemen dejavnik povezovanja in skupnega preučevanja $v$ celotnem šolskem sistemu. S skupnimi projekti šol alpskih dežel bi lahko uresničili mnoge izmed ciljev, ki so zapisani v Zeleni listini o evropski dimenziji izobraževanja.

V nadaljevanju predstavljam možnosti sodelovanja $\mathrm{v}$ duhu evropskih povezovanj na področju geografije med šolami alpskih dežel. 


\section{Splošni cilji:}

- razvijanje spoštovanja značilnih vrednot, identitete, jezika, zgodovine in kulture svoje in sosednjih držav,

- $\quad$ analiziranje skupnih korenin, da bi pretrgali s starimi predsodki in ustvarili razumevanje med generacijami,

- omogočiti mladim ljudem boljši dostop do informacij, razumevanje in kritičnost do okolja in sodobnih problemov, značilnih za vsako skupnost,

- razvijanje avtonomnosti učencev, bodisi pri uporabi razpoložljivih virov informacij ali pri sodelovanju in vključevanju v svoje okolje,

- $\quad$ približati mlade Evropejce drug drugemu tako, da jim vzbudimo zavest o lastni realnosti:

1. a) kakšna je mladina $v$ drugih alpskih državah,

2. b) kako živijo mladi v alpskih državah,

3. c) kako mladi alpskih držav razmišljajo, kaj imajo skupnega,

- prispevati k medsebojnemu sprejemanju, razumevanju in strpnosti,

- $\quad$ vzbuditi zanimanje mladih za:

1) enotnost in raznolikost alpskega sveta in njegove kulturne dediščine,

2) izzive, s katerimi se sooča alpski svet,

3) solidarnost med alpskimi oziroma evropskimi državami in narodi,

- $\quad$ spodbujati skupinsko delo, pri katerem je vsakdo odgovoren za končni rezultat,

- spodbujati ustvarjalnost, intelektualno radovednost otrok in njihovo sposobnost reševanja problemov,

- $\quad$ spodbujati občutek za odgovornost in spoštovanje evropske kulturne in naravne dediščine s poudarkom na Alpah in razvijati zavest enotnosti in raznolikosti,

- razvijanje in negovanje evropske zavesti in evropskega duha,

- prenesti realnost Evrope $\mathrm{v}$ krajevno in regionalno skupnost. 

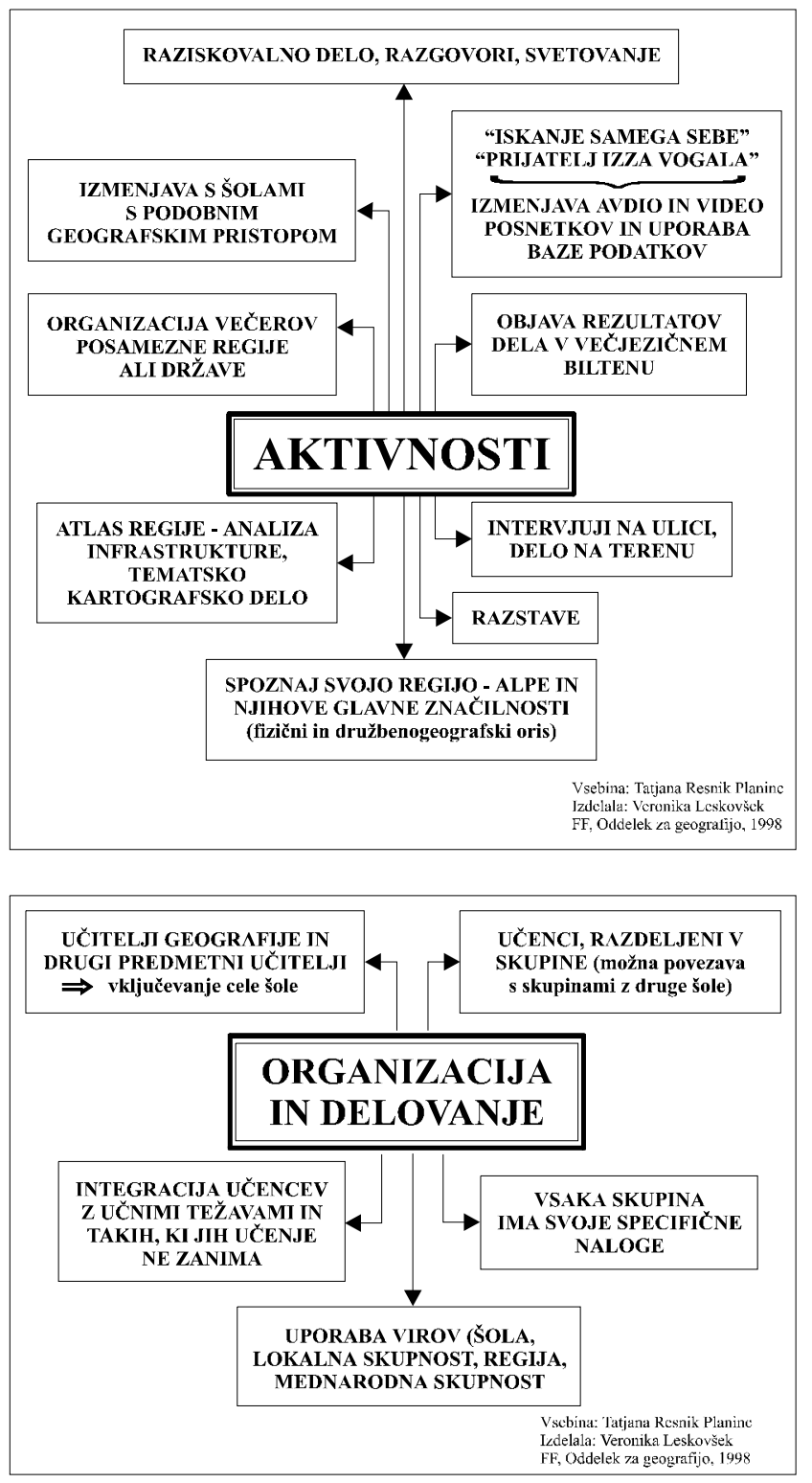


\section{PRIMER SODELOVANJA MED ŠOLAMI ALPSKIH DRŽAV}

V nadaljevanju je predstavljen primer skupnega dela med šolami alpskih držav. Če bi se, na primer, za sodelovanje odločile osnovne šole iz Kranjske Gore, Beljaka in Trbiža, bi lahko vsaka šola pripravila učni list o svojem kraju (gl. primer). Vsi bi imeli isto zamisel, dejavnosti, dodatno delo in povzetek, medtem ko bi se razlikovala slikovno gradivo in besedilo o domačem kraju. Nato bi šole učne liste med sabo zamenjale, otroci bi rešili naloge, sklepe pa bi lahko medsebojno primerjali na skupnem srečanju. Rezultat skupnega dela bi bila "turistična" brošura s skupnimi ugotovitvami in predlogi.

Smiselno je, da se učitelji dogovorijo za učne oblike in metode ter učna sredstva, ki jih bodo pri svojem delu uporabljali. Tako bodo imeli učenci različnih šol že v izhodišču vsaj podobne, če ne že enake razmere za delo.

\section{PRIMER UČNEGA LISTA}

ALPE - ČUDEŽNA DEŽELA

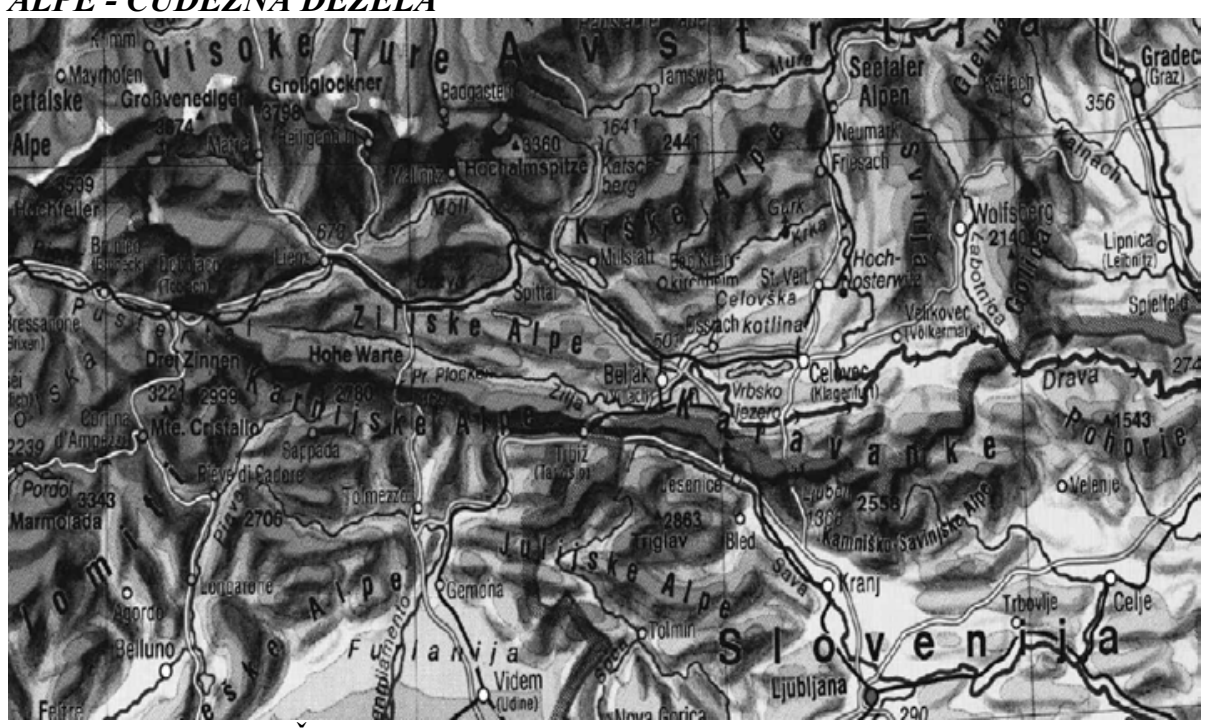

vir: Atlas sveta za OŠ, 1996, 47

"Živimo v Kranjski Gori, gorskem turističnem kraju in pomembnem zimskošportnem središču v slovenskih Julijskih Alpah. Kranjska Gora leži v zgornjem delu Doline ob 
izlivu reke Pišnice v Savo Dolinko, pod vrhovi Vitranca, Male Mojstrovke, Prisojnika in Razorja.

Nekdaj prometno odmaknjena Kranjska Gora, ki je nastala v 14. stoletju, je med 1. svetovno vojno, ko so čez 1611 metrov visok preval Vršič iz doline Save v dolino Soče ruski vojni ujetniki zgradili vojaško cesto, postala strateško pomemben kraj. Zaradi običajno zanesljive snežne odeje od decembra do marca in železnice, ki je vodila skozi Dolino od Jesenic do Trbiža v Italiji (ukinili so jo leta 1966), se je po 1. svetovni vojni začel razvijati zimskošportni turizem.

Kljub turističnemu razvoju se je ohranil stari razpored vaškega naselja. Okrog starega vaškega jedra je zrasel nov, turistični del naselja - hoteli, penzioni in počitniška stanovanja, rekreacijski objekti in trgovsko središče. S sosednjimi naselji (Gozd-Martuljk, Podkoren, Rateče) ter dolinama Planico in Veliko Pišnico predstavlja enotno turistično območje s skupnimi pešpotmi, žičnicami, smučišči ter progami za hojo in tek na smučeh. Pozimi povezuje kraje smučarski avtobus. Prirejamo tudi mednarodna tekmovanja $v$ alpskem smučanju na Vitrancu ter $v$ smučarskih skokih in poletih v Planici. Seveda pa Kranjska Gora ni zanimiva le v zimskem času, ampak s svojo pestro ponudbo in različnimi možnostmi za rekreacijo privlači turiste vse leto. "(Slovenija, 1995, 109 - 114)
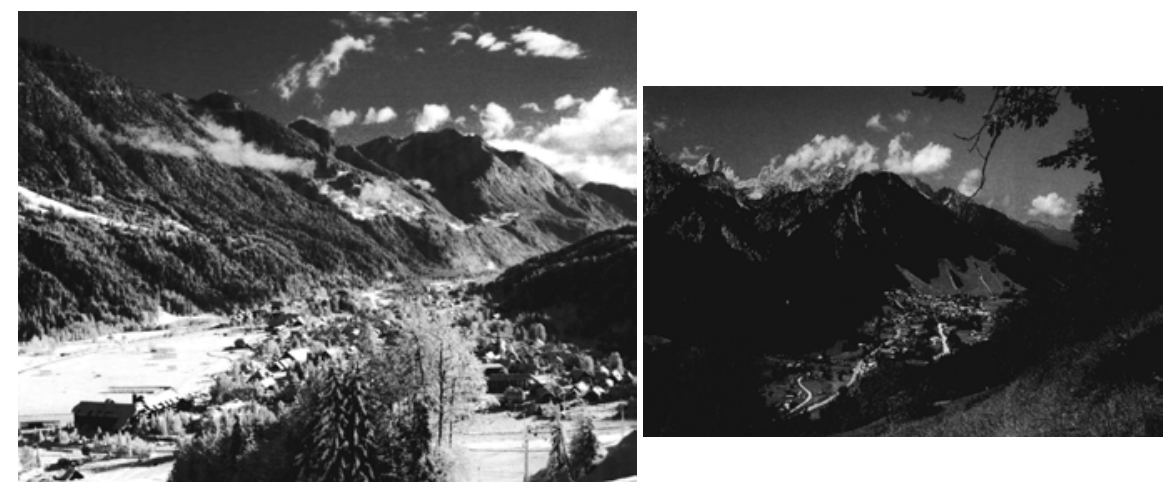

vir: Turistična brošura Kranjska Gora, TD Kranjska Gora, 1998.

"V našem kraju se zelo trudimo, da bi čim manj posegali v naravo in jo uničevali. Vemo, da imajo $v$ marsikaterem alpskem kraju probleme zaradi nepremišljenih posegov v naravo.

Izsekavanje gozda zaradi smučišč lahko povzroči polzenje tal in poplave. Skale in drevesa, ki polzijo po pobočjih, lahko blokirajo reko, uničijo hiše, ceste in kmetijska zemljišča. Medtem ko stavbe in ceste lahko dokaj hitro popravimo, ostane 
obdelovalna zemlja še mnogo let neprimerna za obdelavo. Gorska pobočja si morda ne bodo nikoli povsem opomogla.

Velik problem je tudi veliko število ljudi, predvsem smučarjev. Smučanje je tako priljubljeno, da včasih preprosto ni dovolj prostora za vse. V nekaterih smučarskih središčih v Alpah so se celo odločili, da omejijo število smučarjev. Ko je ta meja dosežena, zaprejo smučišče.

Prepričani smo, da večino problemov lahko rešimo. Potreben je strog nadzor nad gradnjo novih zgradb in smučišč."

\section{DEJAVNOSTI}

1. a) V katerih državah ležijo Alpe?

b) Imenujte tri večja mesta $v$ bližini Kranjske gore.

c) Kolikšna je razdalja med Beljakom oziroma Trbižem in Kranjsko Goro?

2. Glavne zanimivosti Kranjske Gore so:

- lepa pokrajina,

- gore,

- zabava

- divje živali,

- naravno rastlinstvo,

- smučišča,

- restavracije,

- dejavnosti na prostem,

- zanimiva vas,

- trgovine.

Obkrožite tiste zanimivosti, ki jih razberete s priloženih fotografij B in C.

3. Sestavite seznam delovnih mest, povezanih s turizmom, ki bi jih lahko imeli $\mathrm{v}$ Kranjski Gori. Napisati jih morate vsaj 8, poskusite pa izdelati še daljši seznam.

4. Ugotavljanje vpliva posameznih dejavnikov na ljudi in okolje.

a) Naredite kopijo tabele $\check{C}$.

b) S križcem v ustreznem pravokotniku označite, ali ima posamezni dejavnik vpliv na ljudi ali okolje ali na oboje.

c) Pobarvajte pravokotnike s pridobitvami zeleno in pravokotnike s problemi rdeče.

d) Izberite katerikoli problem in predlagajte njegove rešitve. 


\begin{tabular}{|l|l|l|}
\hline Dejavniki & Ljudje & Okolje \\
\hline Nova delovna mesta & & \\
\hline Prometni zamaški & & \\
\hline Preveč ljudi & & \\
\hline Izguba naravne flore in favne & & \\
\hline Srečanja z ljudmi & & \\
\hline Erozija prsti & & \\
\hline Poplave & & \\
\hline Povečanje bogastva & & \\
\hline Neopravljene stvari & & \\
\hline
\end{tabular}

\section{POVZETEK}

Gorska območja postajajo turistično vedno bolj zanimiva. Evropska alpska območja privlačijo veliko število zimskih obiskovalcev. Potrebna je velika skrb, da bi zavarovali okolje.

\section{DODATNO DELO}

Izdelajte stran turistične brošure, ki oglašuje Kranjsko Goro kot smučarsko središče. V besedilo vključite informacije o legi kraja, smučiščih in drugih zanimivostih. Vaša stran naj bo čim bolj zanimiva, pisana in privlačna.

(prirejeno po Weinbrenner, 1998, 62-63) 


\section{ZAKLJUČEK}

Čeprav Slovenija (̌se) ni članica Evropske unije, ji na področju izobraževanja ni treba stati ob strani. Z vključitvijo $\mathrm{v}$ evropske izobraževalne tokove ne bo bogatila samo sebe, ampak bo tudi druge seznanjala s svojim obstojem, vedenjem in znanjem.

Mednarodno sodelovanje na področju izobraževanja je eden od zelo pomembnih dejavnikov povezovanja, ki bogati in vzpodbuja vse sodelujoče, tako učitelje kot učence. Možnosti je nešteto, potrebni so le pogum in volja do dela ter lastno prepričanje o njegovi vrednosti.

\section{VIRI IN LITERATURA}

1. Atlas sveta za osnovne šole. Založba Mladinska knjiga, 1996, Ljubljana, str.47.

2. European Dimension in Teaching. UK Centre for European Education, 1993, London, 56 str.

3. Resnik Planinc, T., 1998: Evropska dimenzija pouka geografije v Sloveniji. Magistrska naloga. Ljubljana, 265 str.

4. Slovenija, turistični vodnik. Založba Mladinska knjiga, 1995, Ljubljana, str. 109114.

5. Teaching for exchanges. Aims and ways of teacher-training. Council of Europe, 1993, Strasbourg, 58 str.

6. The European dimension in regional exchanges. Council of Europe, 1996, Strasbourg, 89 str.

7. Turistična brošura Kranjska Gora. TD Kranjska Gora, 1998, Kranjska Gora.

8. Weinbrenner, U. C., 1998: Erziehung zu europaischer Solidaritat durch geographische Schulbucher der Sekundarstufe I.. Nurnberg, 219 str. 


\title{
EUROPEAN DIMENSION OF TEACHING ABOUT ALPS
}

\begin{abstract}
Summary
Slovenia is one of the countries waiting to become full members of the European union and if so, Slovenia will be expected to implement the European dimension in her education. Education should increase awareness of the growing unity between European peoples and countries and of the establishment of their relations on a new basis. It should also help to make the younger generation conscious of their common European identity without losing sight of their global responsibilities of their national, regional and local roots. It should foster understanding of the facts that, in many spheres of our lives, the European perspective applies to and that European decisions are necessary.
\end{abstract}

To achieve at least some of the goals written in different papers, documents etc. educators need to participate in international exchanges among teachers, schools, pupils and students. There are many possibilities for cooperation in the field of geography teaching. Among all school subjects geography is the one that has a lot to offer.

Exchanges are a fruitful educational experience which brings us new teaching methods, new information, new approaches and ways of work and inventiveness. Considering all mentioned above we have to bear in mind three principles: we have to restore a connection between pupils or students from different countries who normally speak different languages, a joint work, an equality and reciprocity which influence a status of participants and an organization of meetings.

Situated in several European states, Alps can be an extraordinary factor of connection and mutual study in the whole school vertical. With joint projects of the schools of Alpine countries many goals, written in the Green Paper on the European Dimension of Education, could be fulfilled. Among them we could mention a development of typical values, identity, language, history and culture of our own and neighboring countries, an analysis of our mutual roots, to give young people enough information and understanding of contemporary problems, a development of pupils' and students' autonomy, a stimulation of tolerance, group work, creativity, intellectual curiosity together with responsibility and respect of European culture and natural heritage. 